\title{
ESAH ETSU SABA: A BRONZE STOOL FROM NUPELAND
}

\author{
R. O. R. Rom Kalilu*
}

ROM KALILU, R.O. Esah Etsu Saba: a bronze stool from Nupeland. Rev. do Museu de Arqueologia e Etnologia, São Paulo, 4: 141-151, 1994.

RESUMO: Este estudo visa enfatizar a iconografia, iconologia, proveniência idade e significância na História da Arte Nupe e nigeriana de um banco de bronze de valor de antiguidade encontrado em Nupeland, Nigéria. São feitas comparações a objetos de arte similares, yoruba e do Benin, bem como a fontes escritas e orais relevantes. Evidências indicam que o banco pertenceu a Etsu Saba, que governou Nupeland entre 1591 e 1600. O banco é relacionado estilística e morfologicamente a alguns objetos de bronze em Nupeland, Ile-Ife e Benin. Consequentemente, é localizado, tentativamente, no período do séc. XIV ao séc. $\mathrm{XVI}$, no qual aqueles objetos a que está relacionado têm sido datados. Era, provavelmente, uma mercadoria yoruba ou do reino Edo do Benin, destinada a Nupeland.

UNITERMOS: Arte Africana - Bronze - Nigéria - Nupe - Metalurgia.

\section{Introduction:}

The Nupe, who regard themselves as Nupecizi and who have been described as the Black Byzantines (Nadel, 1942) occupy Kin Nupe, their homeland of about 11,200 square kilometres ${ }^{1}$ in the central part of Nigeria; precisely on the low basin of the Niger and the Kaduna rivers' valleys (Nadel, 1942:1). They shared boundaries with the Kamberi, the Kamutu and the Hausa to the north. Their north-eastern and north-western boundaries were respectively shared with the Gwari and the Borgu. The Kakanda and the Yoruba are respectively their neighbours to the south and the southwest (Nadel, 1942:1) (Fig.1).

The Nupe are noted for their skill in certain artistic forms. They are known wood carvers and brass workers. In the 1820 s, the brothers Lander noted their good skill in wood carving (Hallet, 1965:198) while Leo Frobenius in 1911 marvelled at their intricate skill, especially in metal work (Frobenius, 1913:643). This explains the reason for the scholarly attention so far given to their artistic culture. Apart from different art forms such as sculpture in wood and metal, pottery, leatherwork, cloth embroidery as well as cloth weaving; some notable art objects in bronze and copper, variously found in Nupeland, have also been well studied ${ }^{2}$ but not a certain bronze stool of antique importance. The stool, now in the custody of the Niger State Museum and which is the subject of discussion in this paper has only been cursorily mentioned in a doctoral thesis (Kalilu, 1992). 


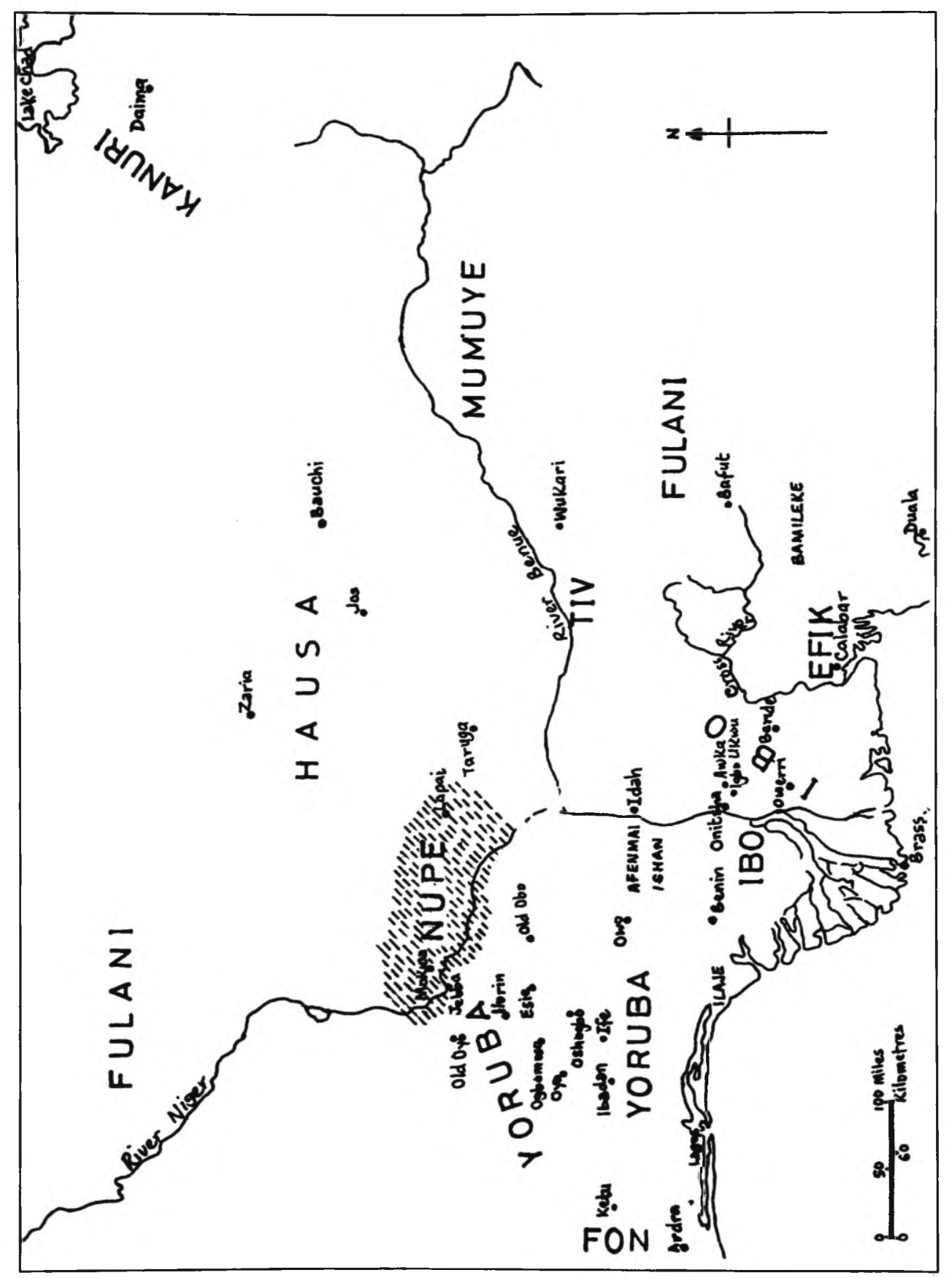

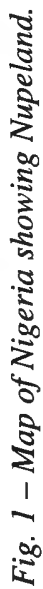


ROM KALILU, R.O. Esah Etsu Saba: a bronze stool from Nupeland. Rev. do Museu de Arqueologia e Etnologia, São Paulo, 4: 141-151, 1994.

\section{Criticism, iconography and iconology}

The stool, which stands at 40 centimetres high, is morphologically cylinderaceous with an almost flat base and top. The top of the stool, which functionally, is the seat is 35 centimetres in diametre. The seat is slightly depressed at the centre, giving it a saucer-like form. The seat is also binded by an interwoven ropelike form at the edge. The stand of the stool is a centrally positioned cylindrical form which tapers towards the base and to a point to- wards its top where it again widens to merge with the saucer-like seat. The base of the stool is a replication of the saucer-like form of the seat but is positioned upside-down and at the centre of which the stool's stand joins. Sprouting from the base of the stool and close to its stand is another cylindrical form, relatively thinner and longer than the stand. This form in its own case is slightly taller than the seat level of the stool and depicted slightly bent and contiguous with the edge of the seat (Pls. 1,2 and 3).

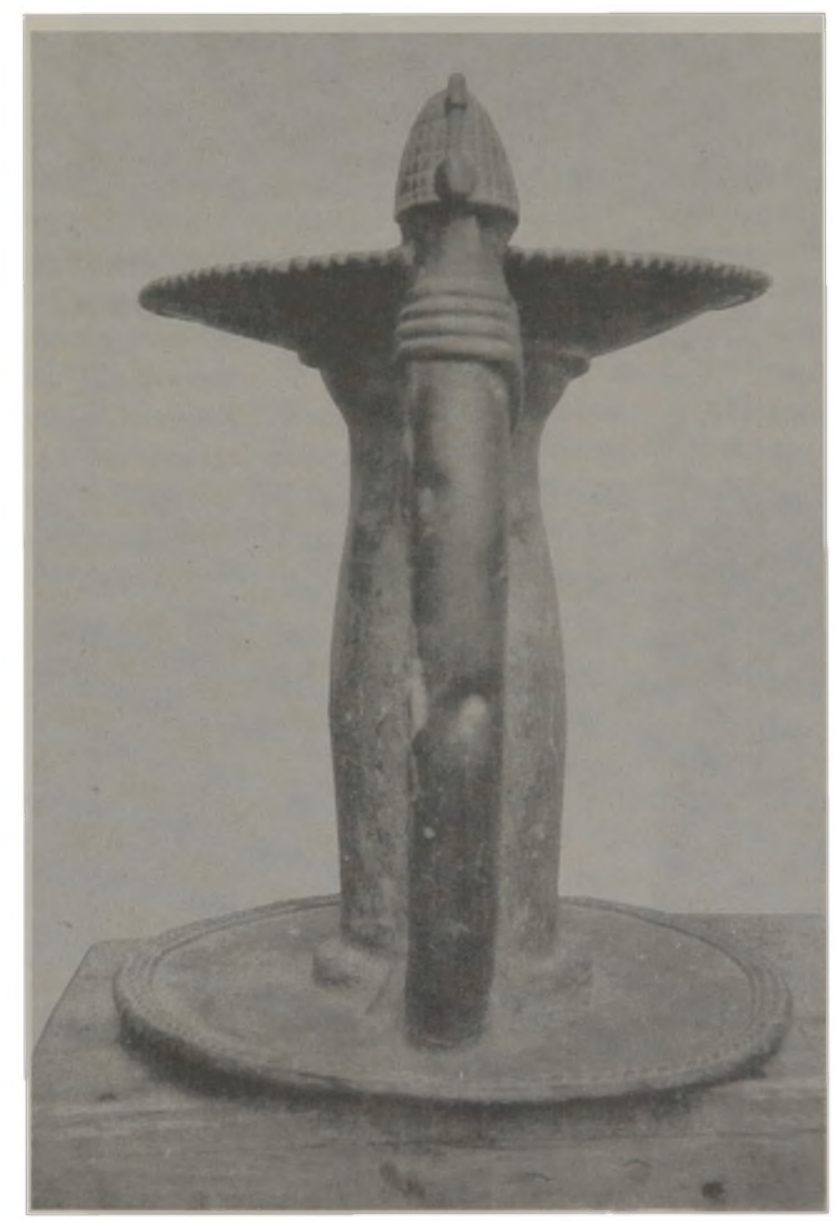

Pl. 1 - The bronze stool from Nupeland. Side view. $H t .40 \mathrm{~cm}$. Niger State Museum, Minna. Photograph: R. O. Rom Kalilu, 1989. 
ROM KALILU, R.O. Esah Etsu Saba: a bronze stool from Nupeland. Rev. do Museu de Arqueologia e Etnologia, São Paulo, 4: 141-151, 1994.

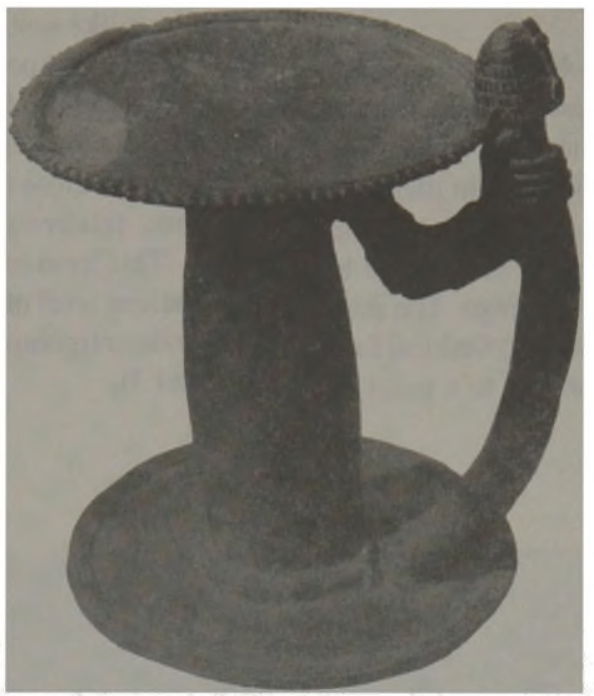

Pl. 2 - Front view of the bronze stool. Note the elaborate beads on the upper and the fore arm depicted on the stool.

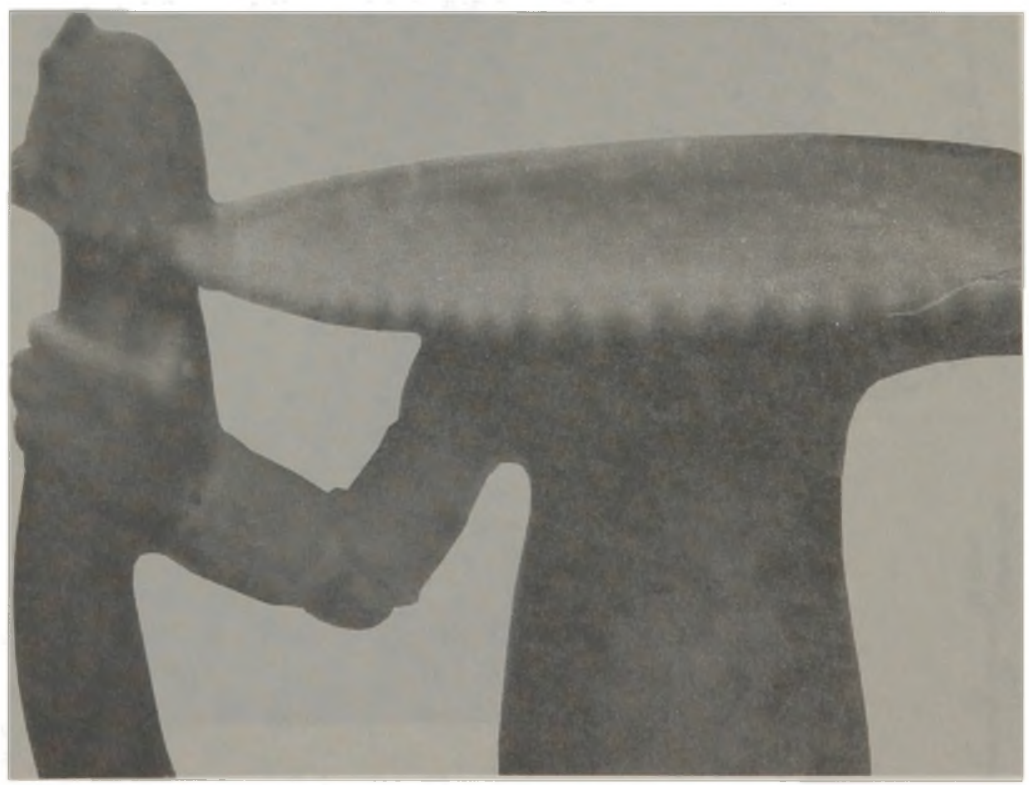

Pl. 3 - A close up of the back view of the bronze stool. 
The cylindrical stand of the stool represents an unclothed human trunk. Modelled interposed between the seat and the cylindrical stand is a shoulder and a left arm. The arm holds the thinner cylindrical form which is undoubtedly a staff of office depicted donning an almost conical beaded headdress with an emblem or a rosette-like form (pls. 1 and 2). The paucity of written and oral records concerning the stool makes the issue of its provenance and iconology a difficult exercise. Nonetheless, the stool appears to be a representation of a royal but more probably a priestly personage holding a staff of office. What is not yet certain however, is who the personage is.

\section{Provenance}

The collection of the other bronze and copper sculptures, discovered in Nupeland (Fig.2) is composed of a male archer, a standing female nude figure from Jebba, a seated male figure, a standing male figure from Tada, two small standing figures, the figure of a male drummer from Giragi, an elephant and two ostriches. The discovery of these sculptures have perplexed scholars because of the technical richness of the sculptures against the artistic poverty of their places of discovery (Nadel, 1942:259). These sculptures are also not in a single or directly related styles and which have made the determination of their origin very controversial. Brass casting is practised in Bida and Kachaa but the Bida centres, located at Tswata Muku, are more famous. However, the technical standard of the contemporary Nupe brass casting, even as early as the early 1940s when Nadel did his authoritative work on the Nupe (Nadel, 1942:259), cannot be reconciled with those of the sculptures.

Nupe tradition associated the sculptures with Tsoede, the legendary founder of the Nupe kingdom, hence they are referred to in some scholarly writings as "Tsoede bronzes". Tsoede was said to have brought the sculptures from Idah, his paternal ancestral home (Palmer, 1936; Hermon-Hodge, 1922; Waker, 1934; Nadel, 1942:73-74; Kalilu, 1992:158). But some authoritative Nupe traditions have denied the Idah origin of the sculptures, while research have also failed to confirm their Idah origin (Kalilu, 1992:158).

Nonetheless, the bronze stool appears to be related to some of the sculptures and should be grouped with them. This does not however pre- clude the fact that the bronze and the copper sculptures from Nupeland might have come from diverse sources as indicated by their stylistic disparities. The treatment of the human shoulder and the arm on the stool shows an understanding of good proportion, weight and strength. It shows a good understanding of forms and context as evident in the ease and the elegance which the personage depicted radiates. The stool also reflects evidence of the sensitive treatment of fleshy forms in an idealised naturalism somehow reminiscent of the seated Tada figure (Pl.4). The seated Tada figure has been dated to the fourteeth century (A.D. $1325 \pm 60$ ) (Adepegba, 1983:26). The headdress on the staff held by the personage is also somehow morphologically related to the almost conical shape of the headdress of the male archer, otherwise known as the Gara figure and which have been dated to the sixteenth to the seventeenth century (Eyo, 1977:160) (compare Pls. 1 and 5). The headdress is also similarly textured in a manner suggestive of beads like those of a bronze figure of a royal personage (Pl.6), and an Ile-Ife stylistically related miniature bronze figure said to be a representation of an Ooni, the traditional ruler of Ile-Ife, and which have been dated to A.D. 142060 (Adepegba, 1983:26) (Pl.7). These two sculptures have been respectively discovered from the Yoruba and the Edo cities of Ile-Ife and Benin (Eyo, 1977:85; Adepegba, 1983:26,28). The headdress on the two figures, have similar emblems as on the bronze stool (compare Pls. 1, 6 and 7).

In its own case, the bronze stool had hitherto been in the custody of the royal house at Bida, from where the Museum acquired it. Oral tradition recalled that the stool was used by Etsu Saba who ruled the Nupe kingdom in the late sixteenth century to the very early part of the seventeenth century. Another tradition also claimed that the stool was used by Masaba, the second Fulani Etsu of Nupe who is said to have ruled about the second half of the nineteenth century. ${ }^{3}$ But if the stool was ever used by Masaba, it appears to have been used first by Etsu Saba because the local name for the stool, Esah Etsu Saba, specifically associates the ownership of the stool to Saba. Saba, succeeded Tsoede in 1591 and ruled over Nupeland till 1600 (Nadel, 1942:406).

(3) Museum label on the stool gives the date as 1592-1602: Niger State Museum, Minna, Nigeria. 
ROM KALILU, R.O. Esah Etsu Saba: a bronze stool from Nupeland. Rev. do Museu de Arqueologia e Etnologia, São Paulo, 4: 141-151, 1994

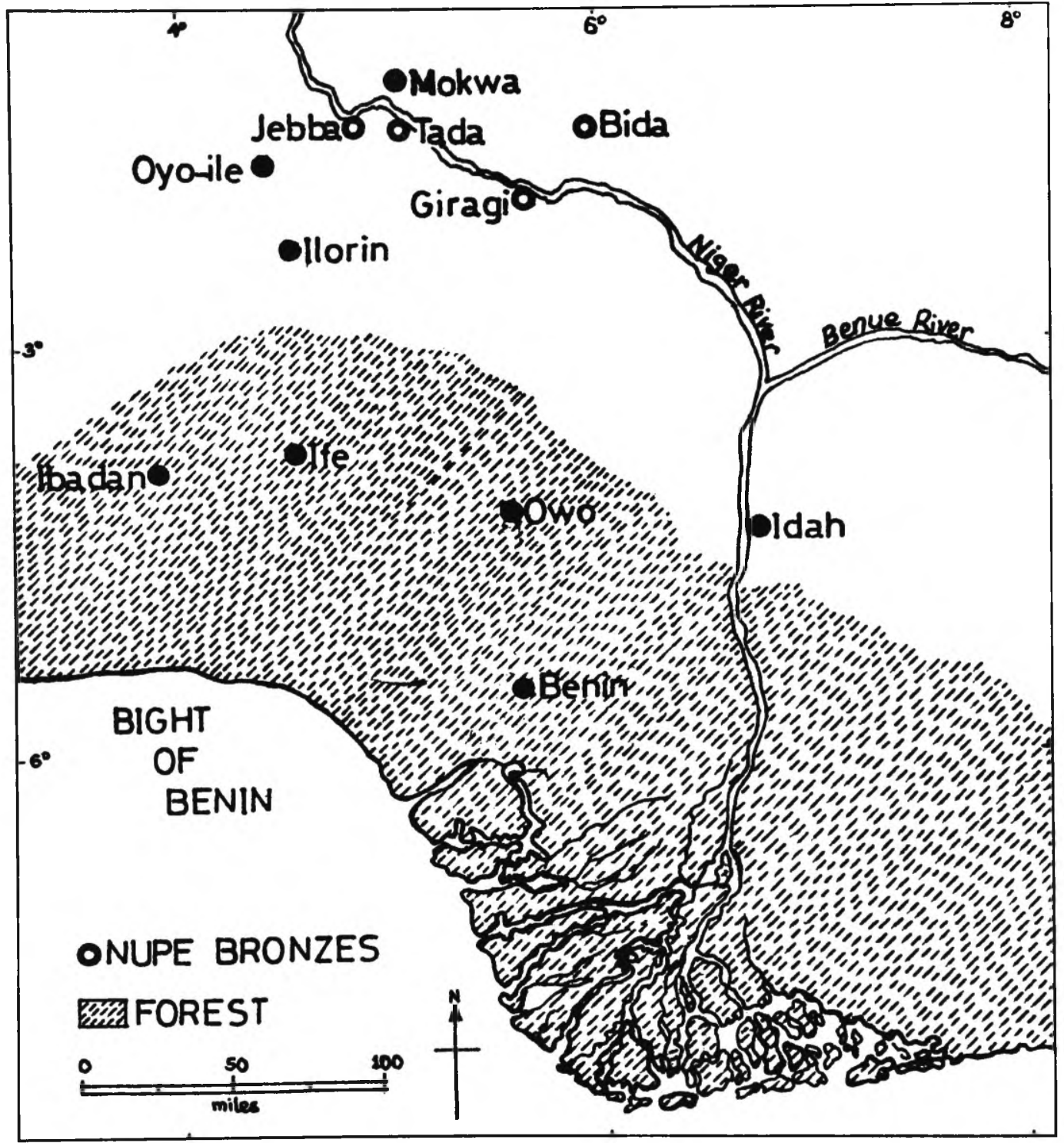

Fig. 2-Map showing places where the bronze and copper sculptures have been discovered in Nupeland. 


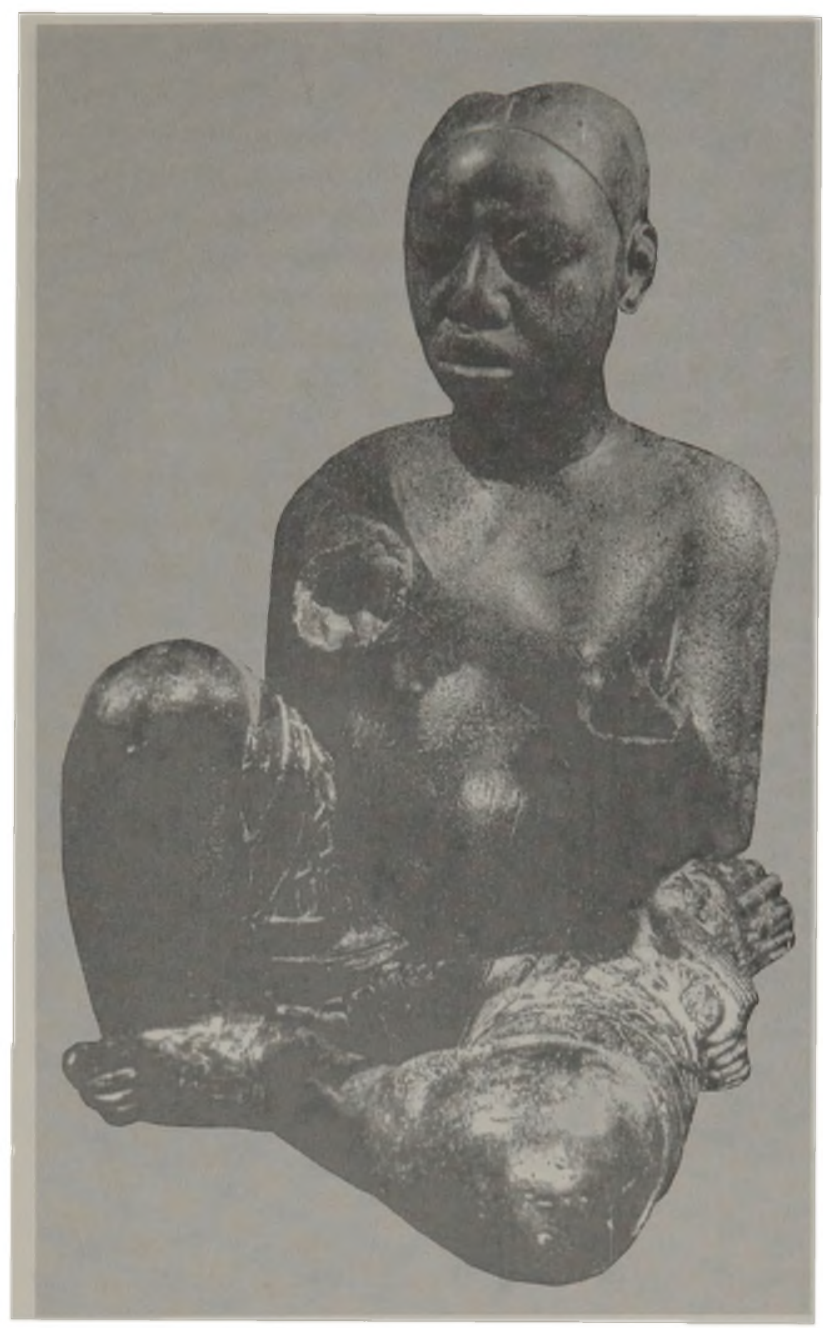

Pl. 4 - The seated Tada figure. Copper. Ht. $53.7 \mathrm{~cm}$. E. Eyo (1977), 164.

\section{Conclusion}

The bronze stool has not been scientifically dated. But the association of its ownership with Etsu Saba tentatively suggests that the stool must have been made at a date not later than the A.D. 1600 and by implication could tentatively be assigned to between the fourteenth century and the seventeenth century date gap to which the other dated bronze and copper sculptures from Nupeland, and to which the stool have been related, have been assigned.
The stylistic and morphological relationship between the stool and some of the other sculptures, and the fact that no tradition or record relates the origin of the stool to Idah tends to weaken the claim for the Idah origin of the other bronze and copper sculptures. But like the other bronze and copper sculptures, it does not appear that the stool was made in Nupeland. Other than their south-western and the far south-western neighbours, the Nupe's other neighbours are not associated with any classical bronze casting tradition of antiquity. The Yoruba and the Edo are respectively the 


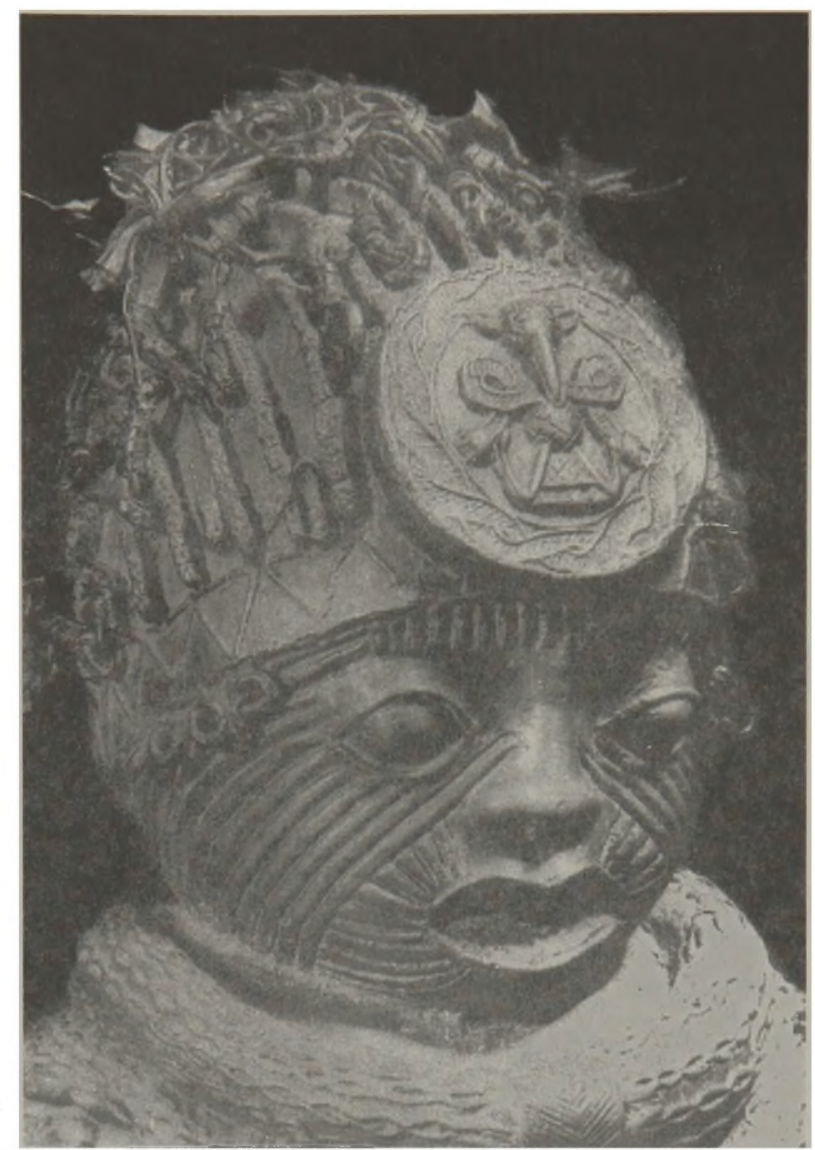

Pl. 5 - Close up view of the almost conical headdress of the male archer. Full height of figure $92 \mathrm{~cm}$. E. Eyo (1977), 160.

Nupe's neighbours to the south-west and the far south-west. The origin of the stool would therefore be one of the Yoruba cities where bronze casting was practised in the pre-seventeenth century, or the Edo city of Benin.

The uncertainty of their places of production notwithstanding, the aforementioned relationship between the stool and the other sculptures as well as the association of the ownership of the stool with Tsoede's successor appears to be an indication that the bronze and copper sculptures did not all get to Nupeland at the same time. There are three possible ways by which the stool could get to Nupeland; as a gift, a booty, or a commodity. The only known instance of the pre-Fulani Etsu of Nupe exchanging gifts with any ruler from their south-western neighbours was that of annual gifts they used to exchange with the ruler of old Oyo kingdom but this did not happen until the eighteenth century (Law, 1973:29). Early history of the Nupe and their south-western neighbours reflects series of hostile martial and friendly commercial relationships. (Law, 1973:29). The Nupe were used to looting the places of their defeated enemies (Nadel, 1942:111-112) at least in their history between the sixteenth century to the seventeenth century. There is however no evidence that the Nupe under Etsu Saba made any incursion into their south-western neighbours' territories or beyond. By the implication of the foregoing, the most likely thing is the stool being a commodity to Nupeland. 
ROM KALILU, R.O. Esah Etsu Saba: a bronze stool from Nupeland. Rev. do Museu de Arqueologia e Etnologia, São Paulo, 4: 141-151, 1994.



Pl. 6 - A royal figure from Ile-Ife. Bronze National Museum, Ile-Ife.

\section{Glossary}

Esah, Nupe word for stool

Etsu, Nupe word for the title of the traditional ruler of the Nupe
Kin Nupe, Nupe word for Nupeland Nupecizi, Nupe word Nupe people 
ROM KALILU, R.O. Esah Etsu Saba: a bronze stool from Nupeland. Rev. do Museu de Arqueologia e Etnologia, São Paulo, 4: 141-151, 1994.

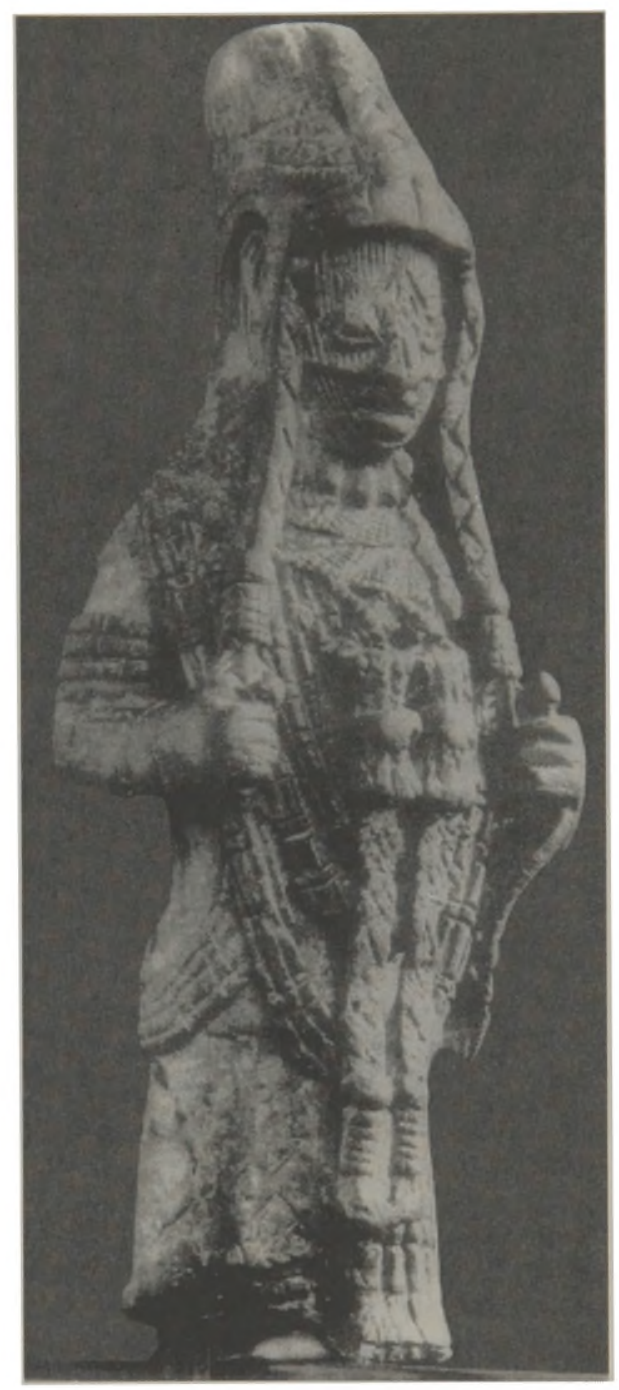

Pl. 7 - A miniature figure from Benin but in Ile-Ife style and said to be the representation of an Ooni, the traditional ruler of IleIfe. Bronze. Ht. $12 \mathrm{~cm}$. E. Eyo (1977), 97. Note the emblem on the headdress. 
ROM KALILU, R.O. Esah Etsu Saba: a bronze stool from Nupeland. Rev. do Museu de Arqueologia e Etnologia, São Paulo, 4: 141-151, 1994.

ROM KALILU, R.O. Esah Etsu Saba: a bronze stool from Nupeland. Rev. do Museu de Arqueologia e Etnologia, São Paulo, 4: 141-151, 1994.

ABSTRACT: A certain bronze stool of antique importance,found in Nupeland, Nigeria, has not been given any serious scholarly attention. This study is made to art historically highlight its iconography, iconology, provenance, age and significance in Nupe and Nigerian art history. The stool is studied vis-a-vis similar art objects from Nupeland, Yorubaland and Benin, as well as relevant oral and written records. Evidence indicate that the stool belonged to Etsu Saba who ruled Nupeland between 1591 and 1600 . It is stylistically and morphologically related to some bronze objects in Nupeland, Ile-Ife and Benin. Consequently, the stool is tentatively assigned to between the fourteenth and the sixteenth century date gap, to which those objects it is related have been variously dated. And it was most likely a commodity to Nupeland from either the Yorubaland or the Edo kingdom of Benin.

\section{UNITERMS: African art - Bronze - Nigeria - Nupe - Metallurgy.}

\section{References}

ADEPEGBA, C. O.

(1983)The question of lineal descent: Nok terracottas to ECCLES, $P$. Ife and the present. African Notes, 9(2)23-32.

(1962) Nupe bronzes, Nigeria Magazine,73:15-25. EYO, E.

(1977) Two thousand years Nigerian art. Federal Department of Antiquities, Nigeria.

FRASER, D.

(1975) The Tsoede bronzes and Owo Yoruba art. African Arts, 8 (3):30-35, 91.

FROBENIUS, L.

(1913) The voice of Africa. Vol.II. Benjamin Bloom, Inc. New York.

HALLET, R. (Ed).

(1965) The Niger Journal of Richard and John Lander. Routledge \& Kega Paul, London.

HERMAN-HODGE, H. B.

(1992) (Langa-Langa) Up against it in Nigeria. New York.

LAW, R. C. C.

(1973)The Oyo kingdom and its northern neighbours. Kano Studies, 1 (1): 25-34.
LAWAL, B.

(1970) Yoruba sango sculpture in historical retrospect. $\mathrm{Ph}$.D. thesis, Indiana University, Indiana.

(1973)The present state of art historical research in Nigeria: problems and possibilities. Journal of Afri-

NADEL, S.F. can History, 18: 193-215.

(1942) A black byzantium. Oxford University Press, London.

PALMER, H. R.

(1936) Gabi figures (from Jebba island). Man, 31: (Art.261).

ROM KALILU, R. O.

(1992) Old Oyo in West African art. Ph. D. thesis, University of Ibadan, Ibadan.

THOMPSON, R. F.

(1970) The sign of the divine king. African Arts, 3 (3): 8-78.

WALKER, S. W.

(1934) Gabi figures and Edegi, first king of Nupe. Man, 34: (Art. 193). 